\title{
Treatment of gonorrhoea with spectinomycin hydrochloride
}

\author{
J. D. STRATIGOS, O. MARSELLOU-KINTI, V. KASSIMATIS, AND G. K. DAIKOS \\ From the First Department of Propaedeutic Medicine, King Paul's Hospital, and the Department of Dermatology, \\ A. Sygros Hospital, Athens
}

In recent years, the increase in the frequency of gonorrhoea has reached alarming levels in many countries (Hart, 1971; Guthe, 1971; Juhlin, 1971; Delune, 1971; Gay-Prieto, 1971). Some believe that gonorrhoea is now 'out of control' mainly because of non-medical factors (Guthe, 1971; Baccareda-Boy and Rebora, 1971; Sparling and McKenzie-Pollock, 1971). Although Neisseria gonorrhoeae is susceptible to various drugs, there is still a need for new drugs that would approach the ideal as closely as possible, i.e. to be highly effective in a single-dose in uncomplicated cases.

Spectinomycin (formerly actinospectacin) is a broad-spectrum antibiotic derived from Streptomyces spectabilis (Hanka, Mason, and Sokolski, 1961; Mason, Dietz, and Smith, 1961; Holloway and Scott, 1963). The sulphate was found to be effective in urogenital infections, especially gonorrhoea (Mason and others, 1961 ; Lindemeyer, Turck, and Petersdorf, 1962; Holloway and Scott, 1963; Vineyard, Mays, and Sanford, 1963). Recently the more soluble hydrochloride derivative has been used to treat gonorrhoea with good results (Platts, 1970; Labowitz, Porter, and Holloway, 1970; Savage, 1971). Cornelius and Domescik (1970), in a more extensive study, found single injections of $2 \mathrm{~g}$. spectinomycin hydrochloride 100 per cent. effective in 108 men and had only four failures among 100 women treated with either 2 or $4 \mathrm{~g}$. We tried the hydrochloride salt of spectinomcyin in seventy male patients suffering from acute gonorrhoea. Our observations are reported below.

\section{Pharmacology}

Spectinomycin sulphate originally proved to be a broad-spectrum antibiotic without serious sideeffects, even in large doses. Slight untoward effects were noticed when the drug was given over long periods. Orally, the drug is poorly absorbed. Intramuscular and intravenous administration of $25 \mathrm{mg}$./ kg. body weight give blood concentrations between 60 to $80 \mu \mathrm{g} . / \mathrm{ml}$. at one hour. A single $2 \mathrm{~g}$. injection

Received for publication, May 17, 1972

Address for reprints: J. D. Stratigos, M.D., 28, Voukourestiou Street, Athens, Greece produces peak serum concentrations averaging 103 $\mu \mathrm{g} . / \mathrm{ml}$. at one hour. The half-life is relatively short ( 2 to $2 \frac{1}{2}$ hours). The drug is eliminated rapidly by the kidneys, 35 to 80 per cent. being excreted in the urine unchanged within 24 hours (Barry and Koch, 1963; Romansky, Walters, Johnson, and Peck, 1962).

\section{Patients and methods}

Spectinomycin hydrochloride was given to seventy male patients aged between 17 and 48 years who were suffering from acute gonorrhoea. The symptoms varied in duration from 24 hours to 4 days. The disease was diagnosed by both smear and culture.

The drug was given in a single dose of $2 \mathrm{~g}$. intramuscularly. Results were assessed clinically and bacteriologically after 24 hours and again after 8 days.

Five out of the original seventy patients defaulted and our results are based on the remaining 65 patients.

\section{Findings}

Gonococci were isolated in all seventy patients before treatment and all strains were inhibited in vitro by discs of $30 \mu \mathrm{g}$. spectinomycin (Table I). Marked improvement in symptoms occurred in all except one patient within a few hours of the injection. Clinical examination 24 hours later revealed only a slight mucous secretion and appearances were normal after 8 days. Table II shows that only one of the 65 patients who attended for follow-up continued to harbour the gonococcus. No side-effects were observed except for slight pain at the site of injection.

TABLE I Minimum inhibitory concentration of spectinomycin (disc method)

\begin{tabular}{|c|c|c|c|}
\hline \multirow{2}{*}{ Inhibition } & \multicolumn{3}{|c|}{ Spectinomycin ( $\mu \mathrm{g})}$. \\
\hline & 100 & 30 & 10 \\
\hline $\begin{array}{l}\text { Strong positive }++++ \\
\text { Positive }+++ \\
\text { Weak positive }+\end{array}$ & $\frac{70}{-}$ & $\frac{70}{-}$ & $\begin{array}{l}38 \\
32 \\
38\end{array}$ \\
\hline
\end{tabular}

\section{Summary and conclusions}

A single injection of $2 \mathrm{~g}$. spectinomycin hydrochloride was used to treat seventy men with acute gonorrhoea. 
TABLE II Results after treatment with spectinomycin

\begin{tabular}{|c|c|c|c|c|c|c|}
\hline \multirow{3}{*}{ No. of patients } & \multicolumn{2}{|c|}{ Clinical examinations } & \multicolumn{4}{|c|}{ Laboratory examinations } \\
\hline & \multirow{2}{*}{ After 1 day } & \multirow{2}{*}{ After 8 days } & \multicolumn{2}{|l|}{$\overline{A f t e r} 1$ day } & \multicolumn{2}{|c|}{ After 8 days } \\
\hline & & & Microscope & Culture & Microscope & Culture \\
\hline 64 & $\begin{array}{l}\text { Slight mucous } \\
\text { secretion }\end{array}$ & No discharge & $\overline{-}$ & $\overline{-}$ & $\overline{-}$ & - \\
\hline 1 & $\begin{array}{l}\text { Purulent } \\
\text { discharge }\end{array}$ & $\begin{array}{l}\text { Purulent } \\
\text { discharge }\end{array}$ & + & + & + & + \\
\hline
\end{tabular}

Only one failure was observed among the 65 men who attended for follow-up. All seventy strains of gonococci were inhibited in vitro by $30 \mu \mathrm{g}$. discs of spectinomycin; this concentration is readily obtained in the blood by the dosage used in this trial. It is concluded that spectinomycin is a satisfactory drug for the treatment of gonorrhoea.

\section{References}

Baccaredda-Boy, A., and Rebora, A. (1971) 'Epidemiological and therapeutic data on gonorrhoea in Genoa and other parts of Italy'. International Meeting on Gonorrhoea, Torremolinos, Spain, March 25-26, 1971 (Brit. F. vener. Dis., 1971, 47, 378)

BARRY, J. M., and Koch, R. (1963) 'Actinospectacin serum levels and clinical data' in 'Antimicrobial Agents and Chemotherapy, 1962', p. 538

Cornelius, C. E., and Domescik, G. (1970) Brit. $\mathcal{F}$. vener. Dis., 46, 212

Delune, H. (1971) 'Epidemiological trend of gonorrhoea in recent years'. International Meeting on Gonorrhoea, Torremolinos, Spain, March 25-26, 1971 (Brit. $\mathcal{F}$. vener. Dis., 1971, 47, 377)

GAY PRIETO, J. (1971) 'Aspects of the present problem of gonorrhoea in Spain'. International Meeting on Gonorrhoea, Torremolinos, Spain, March 25-26, 1971 (Ibid., 47, 377)

GuTHE, T. (1971) 'Present status of gonorrhoea control'. International Meeting on Gonorrhoea, Torremolinos, Spain, March 25-26, 1971 (Ibid., 47, 377)

HaNkA, L. J., Mason, D. J., and Sokolski, W. T. (1961) Antibiot. and Chemother., 11, 123

Hart, M. (1971) F. Amer. med. Ass., 216, 1609

Holloway, J. W., and Scott, G. E. (1963) Clin Med., 70, 1479
JuHLIN, L. (1971) 'Factors which increase the spread of gonorrhoea'. International Meeting on Gonorrhoea, Torremolinos, Spain, March 25-26, 1971 (Brit. $\mathcal{F}$. vener. Dis., 1971, 47, 377)

Labowitz, R., Porter, W. L., and Holloway, W. J. (1970) Delaware med. F., 42, 353

Lindemeyer, R., TURCK, M., and Petersdorf, R. (1962) Amer. F. med. Sci., 244, 478

Mason, D. J., Dietz, A., and SMith, R. M. (1961) Antibiot. and Chemother., 11, 118

Platts, W. M. (1970) Med. F. Aust., 2, 500

Romansky, M., Walters, E., Johnson, A., and Peck, F. (1962) 'Laboratory and clinical studies on actinospectacin-M 141. A new broad-spectrum antibiotic', in 'Antimicrobial Agents and Chemotherapy, 1961', p. 524

SAvAGE, G. M. (1971) 'Gonorrhoea as a world health problem'. 7th International Congress of Chemotherapy, Prague, 1971

Sparling, P. F., and McKenzie-Pollock, J. S. (1971) I. Amer. med. Ass., 216, 1553

VineYard, J., MAYs, B., and SANFord, J. (1963) Clin. Pharm. Ther., 4, 622

\section{Traitement de la gonococcie par le chlorhydrate de spectinomycine}

SOMMAIRE

On a traité par une injection unique de $2 \mathrm{~g}$ de chlorhydrate de spectinomycine 66 hommes atteints de gonococcie aigüe. Un seul échec fut noté parmi les 65 hommes qui se présentèrent pour le contrôle. Toutes les souches de gonocoques étaient inhibées in vitro par $30 \mu \mathrm{g}$ de spectinomycine; cette concentration est facilement obtenue dans le sang par la posologie employée dans cet essai. On conclut que la spectinomycine est un médicament satisfaisant dans la gonococcie. 